\title{
Strategi Pengelolaan Danau Kawah Putih Sebagai Objek Wisata di Kawasan Ciwidey oleh PT. Perhutani (Persero) Unit III Bandung
}

\author{
RIONO GEDE TRISOKO \\ $\&$ \\ RYAN PERDANA PUTRA \\ Dosen Sekolah Tinggi Pariwisata Riau
}

\begin{abstract}
Attraction White Crater Lake Region South Bandung regency has the potential object of sufficient good views of some aspects of the aspects of accessibility, potential aspects, financial aspects, and aspects of marketing and supporting facilities and infrastructure. This potential is supported by the state of nature that is very unique and fascinating. PT Perhutani (Persero) Unit III West Java and Banten made a strategy in developing the Region Attractions Crater Lake White as covering renovation, Certification, held an international event and promotion In Off Line and On Line, as well as improving the quality of the object by organizing support facilities and creating a safe atmosphere, calm and pleasant for pegunjung coming.
\end{abstract}

Keywords: Strategy Management, Attractions

Ciwidey salah satu tempat yang berpotensi sebagai tempat pariwisata yang sekarang ini sedang dikelola oleh Perhutani Bandung selatan. Gunung Patuha oleh masyarakat Ciwidey dianggap sebagai gunung yang tertua, namun patuha berasal dari kata Pak Tua (Sepuh),. Lebih dari seabad yang lalu, puncak Gunung Patuha dianggap angker oleh sehingga masyarakat setempat seringkali menyebutnya dengan nama Gunung Sepuh (tua), sehingga tak seorang pun berani menginjaknya. Oleh karena itu, keberadaannya pada saat saat tersebut tidak sempat diketahui orang.

Danau Kawah Putih ditemukan seorang Belanda bernama Dr. Franz Junghuhn. Sebelum dijadikan tempat wisata, kawasan Ciwidey merupakan kawasan yang dilindung dan hutan selanjutnya karena potensi kawasan alamna dapat dikembangkan untuk kepentingan pariwisata, maka berdasarkan keputusan Mentri Pertanian pada tahun 1978, statusnya diubah menjadi Taman wisata alam.

Ciwidey daerah yang mempunyai suhu udaranya sekitar $8^{0}-22^{0} \mathrm{C}$ banyaknya perkebunan teh dikelola oleh Perhutani, namun dari perkebunan teh masih banyak keindahan dari daerah Ciwidey yaitu di balik Gunung Patuha tersebut adanya sebuah danau Kawah yang sangat indah pemandangannya, yang sekarang oleh Perhutani akan mengembangkan Ciwidey sebagai tempat Pariwisata yang sekarang sedang di kembangkan terus menerus lokasi pariwisata yang ada di Ciwidey.

Danau Kawah Putih terletak di desa Alam Endah, Kecamatan Ciwidey Kabupaten Bandung Jawa Barat yang terletak di kaki gunung Patuha,. Danau Kawah Putih kemudian dijadikan hutan lindung Yang terletak di daerah Ciwidey yang berpotensi dikembang kan menjadi Obyek Wisata Alam, sedangkan Danau Kawah Putih sendiri berada pada ketinggian 2194 m tapi luas total Danau Kawah Putih 25 ha yang dipakai wisata 5 ha dan lokasi kawah sendiri 3 ha. Danau berwarna putih kehijauan dengan batu kapur putih yang mengintari danau tersebut. Disebelah utara berdiri tegak tebing batu kapur berwarna kelabu yang ditumbuhi lumut dan berbagai tumbuhan lainnya, serta fauna kelestarian alam yang masih yang sekarang dikelola dan kembangkan oleh Perhutani kesatuan Pemangkuan Hutan Bandung selatan KPH Bandung Selatan kantornya terletak di Jalan Cirebon No.4 Bandung, perhutani mengembangkan kawasan Wahana Wisata Danau Kawah Putih sejak 1991. Danau Kawah Putih adalah sebuah danau dari gunung Patuha yang terbentuk akibat letusan, pada saat sekarang ini perkembangan Danau Kawah Putih sangat menghawatirkan dari segi jumlah pengunjung dalam priode 3 
tahun ke belakang, namun bila dilihat dari latar belakangnya, memiliki kelebihan dari Kekayaan Alam yang indah dan nilai Sejarah berupa gunung Patuha, Gua belerang khususnya Danau Kawah Putih.

Lokasi jalan menuju tempat Danau Kawah Putih dengan kondisi jalan bagus, tetapi kendaraan roda 6 tidak dapat masuk sampai ke lokasi Danau Kawah Putih karena jalan hanya dapat masuk hanya kendaraan roda 2 dan roda 4. Ruangan informasi yang ada di dekat lokasi Danau Kawah Putih agar memudahkan wisatawan mengetahui di lokasi tentang Danau Kawah Putih lebih jelas. Fasilitas tempat untuk lapangan Parkir Kendaraan pun luas dan tempat kantin pun terdapat di dekat lokasi Danau Kawah Putih.

Untuk menuju Danau Kawah Putih dari gerbang masuk kawasan objek wisata Danau Kawah Putih disarankan menggunakan kendaraan, jangan berjalan kaki karena jalan yang agak menanjak dan cukup jauh, yaitu sekitar 5,6 km atau sekitar $10-15$ menit dengan kendaraan. Kendaraan pribadi dapat langung menuju tempat parkir luas yang tersedia tidak jauh dari kawah. Sementara pengunjung dengan rombongan besar yang menggunakan bis, atau transportasi umum dapat menggunakan kendaraan khusus yang ada di areal parkir dekat gerbang masuk untuk mencapai kawah dari pintu masuk. Kondisi jalan yang kecil dan menanjak tidak memungkinkan untuk dilalui kendaraan jenis bis besar maupun sedang. Transportasi umum menuju Ciwidey dari Bandung dapat ditemui di Terminal Kebun Kalapa maupun Leuwi Panjang. Setelah sampai di Kota Ciwidey maka perjalanan dilanjutkan dengan menggunakan angkutan pedesaan tujuan Situ Patengan. Angkutan pedesaan yang menuju Situ Patengan ini melintasi objek-objek wisata yang ada di kawasan Ciwidey yaitu Perkebunan Strawberry, Danau Kawah Putih, Ranca Upas, kolam renang air panas Cimanggu.

Sejak tahun 1987 PT. Perhutani (Persero) Unit III Jabar dan Banten mengembangkan kawasan Danau Kawah Putih ini menjadi sebuah objek wisata. Untuk tiket masuk areal objek wisata Danau Kawah
Putih, setiap orang dikenakan biaya Rp.15.000.,- sudah termasuk premi asuransi. Objek wisata Danau Kawah Putih dibuka mulai pukul 07.00 dan tutup pada pukul 17.00, setiap hari Senin sampai dengan Minggu. Fasilitas bagi pengunjung di sekitar Danau Kawah Putih sudah cukup memadai dengan adanya areal parkir, transportasi transit menuju kawah, pusat informasi, mushala, dan warung-warung makanan. Untuk menuju ke Danau Kawah Putih, pengunjung dari Jakarta dapat melewati tol Cipularang terus menuju pintu keluar tol Kopo menuju Soreang ke arah selatan ke Kota Ciwidey. Sekitar 20-30 menit dari kota Ciwidey terlihat tanda masuk menuju gerbang masuk objek wisata Danau Kawah Putih yang ada di sebelah kiri jalan. Di kawasan Kawah Putih berjejer penjual makanan dan minuman dengan harga yang cukup terjangkau. Apa bila akan membawa souvenir atau oleh-oleh pulang maka di kawasan tersebut juga sudah ada para penjual souvenir. Souvenir-souvenir itu diolah dengan berbagai macam rupa dan bentuk, ada yang dari batu, ada juga yang terbuat dari pasir.

Sebagai pengelola resmi dari Kawasan Danau Kawah Putih ini, PT. Perhutani (Persero) Unit III Jabar dan Banten harus memiliki strategi yang betul-betul dapat membuat kawasan ini berkembang dan menjadi kawasan wisata yang diminati. PT. Perhutani (Persero) Unit III Jabar dan Banten bekerjasama dengan instansi yang terkait sehingga strategi yang dijalankan dapat terlaksana dengan baik. Dengan melakukan strategi-strategi yang jitu maka diharapkan Kawasan Danau Kawah Putih dapat berkembang dengan cepat.

Menurut Undang Undang Republik Indonesia Nomor 10, Tahun 2009 tentang kepariwisataan menyebutkan bahwa destinasi pariwisata adalah kawasan geografis yang berada dalam satu atau lebih wilayah administratif yang didalamnya terdapat daya tarik wisata, fasilitas umum, fasilitas pariwisata, aksesibilitas serta peran masyarakat yang saling terkait dan melengkapi terwujudnya kepariwisataan. 
Dari pengertian Undang Undang Republik Indonesia Nomor 10, Tahun 2009 dapat digariskan bahwa pembangunan pariwisata perlu ditingkatkan untuk memperluas kesempatan kerja dan kesempatan berusaha, meningkatkan penerimaan devisa serta memperkenalkan alam kebudayaan bangsa Indonesia. Dalam menghadapi perubahan global dan penguatan hak pribadi masyarakat untuk menikmati waktu luang dengan berwisata, perlu dilakukan pembangunan kepariwisataan yang tertumpu pada keanekaragaman, keunikan dan kekhasan bangsa dengan tetap menempatkan kebhinekaan sebagai suatu yang hakiki dalam bingkai Negara Kesatuan Republik Indonesia.

Menurut M.A. Desky (2001:23) wisata merupakan perpaduan beberapa produk wisata, minimal dua pokok, yang dikemas menjadi satu kesatuan harga yang tidak dapat dipisahkan satu sama lain.

Menurut Gamal Suwantoro (1997:4849) produk wisata adalah keseluruhan pelayanan yang diperoleh dan dirasakan atau dinikmati wisatawan semenjak ia meninggalkan tempat tinggalnya sampai ke daerah tujuan wisata yang telah dipilih nya dan kembali kerumah dimana ia berangkat semula. Produk wisata juga merupakan gabungan dari beberapa komponen, antara lain :

1. Atraksi Suatu Daerah Tujuan Wisata.

2. Fasilitas yang tersedia.

3. Aksesbilitas ke dan dari tujuan wisata.

Menurut Nyoman S. Pendit (1996:135) kebijakan kepariwisataan dapat dirumuskan sebagai berikut: "segala sesuatu tindakan instansi Pemerintah dan badan/organisasi masyarakat yang mempengaruhi kehidupan kepariwisataan itu sendiri".

Menurut Peraturan Daerah Propinsi Jawa Barat Nomor 4 Tahun 2004 tentang Rencana Induk Pengembangan Pariwisata disebutkan bahwa potensi objek dan daya tarik wisata dibagi menjadi 3 (tiga) bagian, yaitu :

1. Potensi objek dan daya tarik wisata budaya terdiri dari peninggalan budaya, adat istiadat daerah, musik tradisional, hasil karya seni suara, tari, lukis, pahat yang dapat memberikan daya tarik wisatawan.

2. Potensi objek dan daya tarik wisata alam terdiri dari segala keindahan alam meliputi gunung, hutan, pantai, gua, dan panorama yang lain.

3. Potensi objek dan daya tarik wisata minat khusus terdiri dari segala sesuatu yang dapat menarik wisatawan berkunjung ke suatu tempat.

Menurut Kesrul, (2003:4) Pariwisata adalah usaha yang dilakukan agar wisatawan dapat menikmati karya cipta Tuhan dan memahaminya serta mensyukuri sebagai bagian dari karunia Tuhan, Kepariwisataan ialah kegiatan bersukacita yang dilakukan untuk menikmati karunia dan rahmat Tuhan. Masih Menurut Kesrul, (2003:3) Wisata diartikan sebagai bentuk sebuah perjalanan yang direncanakan disusun oleh perusahaan perjalanan dengan waktu seefektif mungkin dengan menggunakan fasilitas-fasilitas pendukung wisata lain, guna membuat peserta tour merasa senang dan puas.

Selanjutnya menurut Happy Marpaung, (2002:13) wisatawan adalah orang yang mengadakan perjalanan dari tempat kediamannya tanpa menetap ditempat yang didatanginya, atau hanya untuk sementara waktu tinggal yang didatanginya.

Mereka dikatakan wisatawan karena :

a. Orang-orang yang sedang mengadakan perjalanan untuk bersenang-senang, untuk keperluan pribadi, kesehatan, dan sebagainya.

b. Orang-orang yang sedang mengadakan perjalanan untuk maksud menghadiri pertemuan, konferensi, musyawarah, atau didalam hubungan sebagai utusan berbagai badan/ organisasi (ilmu pengetahuan, administrasi, diplomatik, olahraga, keagamaan, dan sebagainya).

c. Orang-orang yang sedang mengadakan perjalanan dengan maksud bisnis.

d. Pejabat pemerintah dan orang-orang militer beserta keluarganya yang diposkan di suatu negara lain, maka hal ini dapat digolongkan sebagai wisatawan. 
Menurut Oka A. Yoeti, Pengantar Ilmu Pariwisata, (2007:28) yang berisi tentang, Hal- hal yang perlu diperhatikan dalam pengembangan suatu obyek wisata:

1. Obyek wisata itu harus mempunyai apa yang disebut sebagai "Something to see ", artinya di tempat tersebut harus mempunyai daya tarik khusus yang dapat dilihat terutama yang berbeda dengan yang dimiliki tempat lain.

2. Dilokasi obyek wisata itu harus tersedia dengan apa yang disebut "Something to $d o$ ". Artinya di lokasi tersebut harus pula ada kegiatan yang dilakukan, contohnya fishing, traking, dan lain-lain.

3. Dilokasi obyek wisata tersebut harus tersedia apa yang disebut dengan " Something to buy " yang artinya dilokasi tersebut harus terdapat fasilitas untuk berbelanja (Shopping) terutama souvenir sebagai oleh-oleh untuk dibawa pulang.

Menurut Kaelany H. D, (2007: 20) yang menyebutkan Potensi merupakan kelebihan dan daya tarik wisata yang dimiliki suatu obyek wisata.

Menurut R. S. Damardjati (2001:3536) Dinas Pariwisata Daerah (DIPARDA), merupakan aparat atau instansi kelengkapan dalam struktur pemerintahan Daerah Tingkat I/ Propinsi ataupun Tingkat II/ Kabupaten/ Kotamadya, yang dibentuk dan ditugasi untuk menangani dan mengelola segi-segi administrasi, serta merupakan badan pelaksana/eksekutif untuk kebijaksanaan pemerintah daerah yang menyangkut pengembangan, pengelolaan dan pengaturan soal-soal kepariwisataan di daerah bersangkutan. Kebijaksanaan dan administrasi operasional ini tentu saja tetap mengacu kepada kebijaksanaan dan ketentuanketentuan/peraturan-peraturan yang telah ditetapkan dan digariskan dari pusat maupun tingkat nasional.

Menurut Bahar (2009 : 28) mengatakan bahwa strategi pengembangan pembangunan terbagi ke dalam 4 (empat) macam yakni:

\section{Strategi Intensifikasi}

Yaitu pemanfaatan produk yang ada dalam arti lebih fokus pada pemanfaatan kapasitas yang telah dimiliki untuk melayani pasar yang ada dan pasar potensial.

2. Strategi Ekstensifikasi

Yaitu upaya untuk menciptakan produkproduk baru bagi pasar lama (saat ini) melalui pengembangan dilokasi-lokasi lain.

3. Strategi diversifikasi

Yaitu menciptakan produk-produk yang beraneka ragam untuk segmen pasar yang berbeda-beda.

4. Strategi Konsolidasi

Yaitu peningkatan pemanfaatan komponen-komponen pembangunan yang telah ada atau dikembangkan dengan cara melengkapi dengan komponen yang lain sesuai dengan yang diperlukan.

Bahar Ajib (1980: 43) menyatakan bahwa suatu seni budaya perlu dilestarikan jika ditinjau dari nilai-nilai seni budaya yang ditinggalkan, khususnya untuk bangsa Indonesia yang memiliki seni budaya yang beragam, dimana seni budaya Indonesia merupakan salah satu aset bangsa dan dapat dijadikan suatu tradisi dari peninggalanpeninggalan sejarah, tetapi juga seni budaya dapat dinilai dari tradisi dan adat istiadat yang dilestarikan oleh setiap anak cucu yang ditinggalkan. Menurut Samsuridjal dan Kaelany (1990: 37), berhasilnya suatu tempat berkembang menjadi daerah tujuan wisata sangat tergantung pada 3 faktor utama yaitu :

1. Atraksi, dapat dibedakan menjadi :

a. Tempat, seperti tempat dengan iklim yang baik, pemandangan yang indah atau tempat-tempat bersejarah

b. Kejadian peristiwa, kongres, pameran atau peristiwa-peristiwa olah raga, festival dan sebagainya

2. Mudah dicapai (aksesbilitas)

Tempat tersebut dekat jaraknya, atau tersedianya transportasi ke tempat itu secara teratur (sering), murah, aman dan nyaman.

3. Amenitas

Tersedianya fasilitas-fasilitas seperti tempat-tempat penginapan, restoranrestoran, tempat hiburan, transportasi 
lokal yang memungkinkan wisatawan bepergian di tempat itu serta alat-alat komunikasi lainnya.

Adapun tujuan penyelenggaraan kepariwisataan menurut Sri Wulandari (2001:23) adalah untuk :

1. Memperkenalkan, mendayagunakan, melestarikan dan meningkatkan mutu objek dan daya tarik wisata

2. Memupuk rasa cinta tanah air dan meningkatkan persahabatan antar bangsa

3. Memperluas dan meratakan kesempatan berusaha dan lapangan kerja

4. Meningkatkan pendapatan nasional dalam rangka meningkatkan kesejahteraan dan kemakmuran rakyat

5. Mendorong pendayagunaan produksi Nasional

Objek wisata merupakan dasar bagi kepariwisataan. Tanpa adanya daya tarik di suatu daerah tertentu maka kepariwisataan sulit untuk dikembangkan. Pariwisata biasanya akan dapat lebih berkembag atau dikembangkan jika disuatu daerah terdapat lebih dari satu objek wisata.

Menurut Salah Wahab (1992:28), pemasaran wisata adalah proses manajemen dimana organisasi pariwisata Nasional dan/ atau badan-badan usaha wisata dapat mengidentifikasi wisata pilihannya baik yang aktual maupun potensial, dapat berkomuniukasi dengan mereka untuk meyakinkan dan mempengaruhi kehendak, kebutuhan, motivasi, kesukaan dan hal yang tidak disukai, serta merumuskan dan menyesuaikan produk wisata mereka secara tepat, dengan maksud mencapai kepuasan optimal wisatawan sehingga dengan begitu mereka dapat meraih saran-sarannya.

\section{METODE}

Penelitian DIlakukan di PT. Perhutani (Persero) Unit III Jabar dan Banten Di Jalan Cirebon No.4 Bandung - Jawa Barat Indonesia dengan menggunakan populasi dalam penelitian ini adalah Pengelola PT. Perhutani (Persero) Unit III Jabar dan Banten, dan wisatawan yang datang ke Kawasan Wisata Danau Kawah Puth Ciwidey. Yang menjadi sampel dalam penelitian ini adalah: 1 orang Pimpinan Pengelola; 6 orang Divisi Pengembangan; 1 orang personalia; dan 80 orang wisatawan. Data dikumpulkan dengan menggunakan kuesioner dan kemudian dianalisis serta diolah dengan menggunakan metode Deskriptif Analitik.

\section{HASIL}

\section{Strategi Yang Dilakukan Dalam Mengelola Kawasan Wisata Danau Kawah Putih Oleh PT. Perhutani (Persero) Unit III Bandung.}

Di kawasan ini terdapat objek wisata menarik yaitu Kawah Putih. Kawah Putih adalah sebuah danau kawah dari Gunung Patuha dengan ketinggian 2.434 meter di atas permukaan laut dengan suhu antara $8-22^{\circ} \mathrm{C}$. Di puncak Gunung Patuha itulah terdapat Kawah Saat, saat berarti surut dalam Bahasa Sunda, yang berada di bagian barat dan di bawahnya Kawah Putih dengan ketinggian 2.194 meter di atas permukaan laut, kedua kawah itu terbentuk akibat letusan yang terjadi pada sekitar abad X dan XII silam.

Kawah Putih ini terletak sekitar 46 $\mathrm{km}$ dari Kota Bandung atau $35 \mathrm{~km}$ dari ibukota Kabupaten Bandung, Soreang, menuju Ciwidey. Alam pemandangan di sekitar Danau Kawah Putih cukup indah, dengan air danau berwarna putih kehijauan, sangat kontras dengan batu kapur yang mengitari Danau Kawah Putih. Di sebelah utara danau berdiri tegak tebing batu kapur berwarna kelabu yang ditumbuhi lumut dan berbagai tumbuhan lainnya.

Dengan tiket masuk yang cukup tinggi, terutama untuk satu mobil Rp 150.000 dan per orang dewasa di tarik Rp 16.000. Pilihan lainnya adalah parkir di bawah, dan naik kendaraan Rp 23.000 pulang pergi ke lokasi kawah, dan harus menunggu penumpang penuh dulu. Dari pintu gerbang hingga ke kawah jaraknya sekitar 5, $6 \mathrm{~km}$ atau bisa ditempuh sekitar 20-30 menit. Melalui jalan beraspal yang berkelok-kelok dengan pemandangan hutan alam dengan aneka ragam species tanaman. Danau Kawah Putih terletak di sebuah gunung yang 
bernama Gunung Patuha. Dahulu kala, masyarakat menganggap kawah ini kawasan yang angker karena banyak burung mati seketika melewati kawah ini.

Kepercayaan inipun lantas dibantah, ketika pada tahun 1837 seorang ilmuwan Belanda Jerman Dr. Franz Wilhelm Junghun yang juga seorang pengusaha perkebunan Belanda yang mencintai kelestarian alam melakukan penelitian dan menemukan bahwa keangkeran tersebut tidak lain disebabkan oleh adanya semburan lava belerang yang berbau sangat menyengat. Namun saat ditemukannya fakta tersebut masyarakat belum tertarik menjadikan tempat ini sebagai objek wisata.

Baru setelah PT Perhutani mengembangkan tahun 1987, kawasan Danau Kawah Putih dijadikan sebuah objek wisata di Jawa Barat. Air kawah di gunung ini selain warna airnya yang terang dan juga selalu berubah-ubah. Inilah yang pada akhirnya menjadi daya tarik tersendiri. permukaan kawah umumnya berbatu dan berpasir warna putih, sehingga kawah ini kemudian dikenal sebagai Danau Kawah Putih. Beberapa peneliti mengatakan bahwa gunung Patuha masih aktif, sehingga ditemukan beberapa pancaran kawah yang masih bergejolak. Di dekat tempat ini pula ditemukan sebuah goa sedalam 5 meter yang pernah dipakai sebagai tambang belerang. tak heran jika beberapa kawah tiba-tiba beruap banyak, dan pengunjung didapati terbatuk-batuk akibat menghirup hawa belerang yang berbau sangat tajam. Tak mengherankan peringatan di papan pengunjung kunjungan ke sekitar kawah tak boleh lebih dari 20 menit, terlebih saat berkunjung terkadang hujan rintik turun disertai kabut tipis. Tapi inilah suasana yang eksotik dan jarang dijumpai jika berkunjung ke pegunungan yang aktif.

Suhu di sekitar kawah memang sejuk sepanjang hari bersuhu sekitar $8-22^{\circ} \mathrm{C}$. Mungkin karena kawah ini terletak di gunung yang memiliki ketinggian sekitar $2.434 \mathrm{~m}$ diatas permukaan laut. Bahkan, jika sudah mengetahui keajaiban alamnya, pasti akan mengatakan tak ada kawah yang seindah Danau Kawah Putih. Karena keindahan alamnya, Danau Kawah Putih sering dijadikan tempat photo prawedding, syuting film dan sinetron.

Tempat wisata kawah putih ciwidey sepertinya sudah siap go internasional, itu di buktikan dengan semakin meningkatnya turis asing yang mengunjungi tempat tersebut, Obyek wisata taman nasional Kawah Putih Ciwidey, yang terletak di kecamatan Rancabali, Kabupaten Bandung, diproyeksikan akan menjadi obyek pariwisata bertaraf Internasional. mungkin tidak lama lagi tempat wisata kawah putih ini akan menyusul menjadi wisata yang terkenal di luar negri seperti bali, dengan objek wisata yang menarik dan dilengkapi fasilitas yang memadai maka tidak menutup kemungkinan tempat wisata kawah bali ini akan rame pengunjung.

Lius Lottong, Manager Operasional objek wisata ini mengatakan jika persiapan untuk menuju obyek pariwisata bertaraf Internasional tersebut dibutuhkan kurun waktu tiga tahun. untuk itu sangat dibutuhkan strategi-strategi dari pengelola yaitu PT. Perhutani (Persero) Unit III Jabar dan Banten dalam menjadikan Danau Kawah Putih sebagai objek wisata yang dapat diunggulkan di Kawasan Bandung Selatan. PT. Perhutani (Persero) Unit III Jabar dan Banten memiliki beberapa strategi yang dijalankan dalam mengelola Kawasan Danau Kawah Putih yaitu:

1. Melakukan Renovasi

Dalam hal ini manajemen dan pengelola wanawisata Kawah Putih, telah melakukan renovasi untuk membuat kawasan tersebut rapi, tertib, dan modern hingga menjadi destinasi wisata internasional. Berbagai renovasi yang dilakukan bertujuan untuk meningkatkan kunjungan wisatawan ke Kawasan Danau Kawah Putih.

\section{Melakukan Sertifikasi}

Sertifikasi adalah suatu pengakuan yang di berikan kepada suatu objek wisata yang diakui oleh internasional bahwa objek wisata tersebut termasuk kedalam kekayaan wisata dunia yang diakui melalui sebuah sertifikat yang dikeluarkan oleh UNESCO. Di objek Kawah Putih ini untuk proses 
sertifikasi agar menjadi objek wisata internasional pun sedang dalam proses pengurusan lembaga sensor wisata. Sertifikasi ini bertujuan agar objek wisata Danau Kawah Putih Ini dapat diakui sebagai objek wisata internasional, dengan demikian pengunjung dari luar negeri diharapkan akan banyak mengunjungi tempat ini. Dua tahun ini, jumlah wisatawan memang mengalami lonjakan hingga dua kali lipat. Memasuki libur sekolah serta libur Lebaran mendatang, pengelola kawasan wisata Kawah Putih menargetkan 30.000 pengunjung baik wisatawan mancanegara maupun domestik. Jumlah itu diyakini akan tercapai didukung dengan sejumlah peningkatan infrastruktur yang kini disiapkan pengelola. Jumlah pengunjung hari hari biasa, rata-rata mencapai 800 hingga 1.000 orang per hari. Namun saat liburan, jumlah pengunjung bisa membeludak hingga mencapai 10 persen.

\section{Menggelar Acara Event Bertaraf Internasional}

Pengelola juga menggelar event bertaraf Internasional, yang sebelumnya pernah digelar di Kawah Putih, yakni Festival Kawah Putih. Ini dilakukan untuk menjadikan Kawah Putih ke dunia Internasional, dengan perencanaan yang matang, apalagi menyelenggarakan festival maka kemungkinan besar lonjakan para turis lokal maupun mancanegara akan membeludak di tambah lagi di manjakan dengan pemandangan-pemandangan yang indah dan jarang dijumpai di tempat lain maka akan mendukung tercapainya tempat wisata ini Go Internasional.

4. Melakukan promosi Secara Off Line Dan On Line

Tidak semua Wisatawan akan langsung mengetahui tempat Danau Kawah Putih dan mengetahui alamat situs, Untuk itu maka perlu melakukan strategi distribusi secara off line terlebih dahulu dengan cara:
a. Membuat Ikan di majalah disertai dengan alamat situs
b. Membuat Brosur dimana Wisatawan dari kalangan atas sampai bawah dapat

mengetahui alamat lokasi dan alamat situs

Promosi merupakan salah satu kegiatan yang sangat vital yang harus dilakukan pebisnis internet, kegiatan ini menentukan tingkat keberhasilan dari produk dan jasa yang dipasarkannya terjual. Di internet ada berbagai media yang bisa kita gunakan untuk melakukan promosi bahkan dengan gratis sekalipun, mulai dari pasang iklan baris, kirim email ke teman, memberikan ebook gratis dengan konsep viral marketing dan sebagainya.

Mungkin ini yang dicari banyak orang, promosi dengan tanpa modal alias gratis dan bisa berjalan secara otomatis. Sudah tentu bahwa internet adalah gudang informasi, dimana orang pergi ke internet adalah mencari informasi yang dibutuhkan. Dalam mencari informasi tersebut $80 \%$ adalah menggunakan search engine seperti Google dan Yahoo sebagai mesin pencarinya karena dianggap mampu menampilkan hasil pencarian yang akurat sesuai keinginan.

Untuk secara on line alamat web ini dapat ditemukan oleh wisatawan, diperlukannya media pendukung seperti iklan majalah dan brosur adalah media informasi. Dari media pendukung tersebut dicantumkannya alamat situs agar wisatawan dapat mengetahui alamat situs tersebut. Agar website Danau Kawah Putih dapat diakses oleh wisatawan, maka terlebih dahulu harus mendaftarkan alamat website ini kesalah satu server layanan internet.

Beberapa strategi pengelolaan itu dikarenakan beberapa alasan yakni:

1. Adanya strategi pengelolaan yang lebih terarah maka diharapkan Kawasan Danau Kawah Putih dapat lebih dikembangkan lagi.

2. Dengan adanya strategi tersebut diharapkan adanya peningkatan jumlah kunjungan wisatawan sehingga lebih banyak menghasilkan devisa bagi daerah dan juga dapat meningkatkan perekonomian masyarakat tempatan.

3. Diharapkan agar Kawasan Danau Kawah Putih lebih dikenal oleh masyarakat 
umum terutama wisatawan nusantara dan mancanegara.

\section{Hambatan-Hambatan Dalam Mengelola Kawasan Wisata Danau Kawah Putih Oleh PT. Perhutani (Persero) Unit III Bandung}

Walaupun Objek Wisata Kawah Putih memiliki pesona yang sangat mengagumkan namun pengelolaan yang dilakukan oleh PT. Perhutani (Persero) Unit III Jabar dan Banten mengalami kesulitan dan hambatanhambatan. Hal ini lah yang menjadi penyebab sehingga Kawasan Danau Kawah Putih masih kurang berkembang. Beberapa hambatan yang dialami oleh PT. Perhutani (Persero) Unit III Jabar dan Banten dan pengelolaan Kawasan Danau Kawah Putih adalah sebagai berikut:

1. Pengembangan masih fokus pada aspek fisik saja

Pengembangan dan pengelolaan kawasan Danau Kawah Putih Oleh PT. Perhutani (Persero) Unit III Jabar dan Banten masih fokus hanya pada pengembangan aspek fisik saja, seperti hanya mengembangkan karena potensi alamnya. Saat ini dalam pengembangan kegiatan pengelolaan belum terlihat upaya menciptakan obyek pariwisata baru yang bersifat non-fisik, seperti dengan mengembangkan potensi kebudayaan yang dimiliki oleh daerah tersebut, apakah upacara adat yang dimiliki atau kegiatan unik yang ada dan berpotensi untuk dikembangkan sebagai tempat wisata nasional di Kawasan Objek Wisata Kawah Putih.

2. Kurangnya ketersediaan dana

Dalam kegiatan pariwisata tidak terlepas dari adanya dana sebagai penunjang dalam pengelolaan obyek pariwisata. Dana yang ada tentunya dapat digunakan untuk memperbaiki kekurangan-kekurangan pada obyek wisata. Namun terkadang dana yang ada belum mampu untuk memperbaiki obyek wisata yang seharusnya dibenahi. Sehingga hal ini dapat menganggu kelancaran dalam pengembangan obyek wisata. Faktor dana dalam meningkatkan pengembangan obyek wisata tidak dapat diukur secara pasti, karena dana didapat apabila terdapat kerusakan. Dengan adanya hal tersebut tentunya menghambat pengembangan obyek wisata
Kawasan Danau Kawah Putih yang diinginkan. Adanya keterbatasan dana dalam pengembangan Kawasan Danau Kawah Putih Oleh PT. Perhutani (Persero) Unit III Jabar dan Banten, menyebabkan suatu obyek wisata Danau kawah Putih masih belum berkembang dengan maksimal.

3. Permasalahan-permasalahan dalam konteks lokal

Sering ditemui antara lain dalam pelaksanaan kegiatan pengelolaan oleh PT. Perhutani (Persero) Unit III Jabar dan Banten yaitu masih banyak terjadi masyarakat yang berada di dalam kawasan wisata tersebut masih belum ikut "memiliki", manfaat yang dihasilkan belum sepenuhnya dirasakan oleh masyarakat di sekitarnya hanya dirasakan oleh para investor saja yang turut menanamkan modalnya di Kawasan Danau Putih tersebut.

\section{SIMPULAN}

Objek wisata Kawasan Danau Kawah Putih Kabupaten Bandung Selatan memiliki potensi objek yang cukup memadai baik dilihat dari beberapa aspek yakni aspek aksesibilitas, aspek potensi, aspek financial, dan aspek pemasarannya serta sarana maupun prasarana pendukungnya. Potensi ini didukung oleh keadaan alam yang sangat unik serta mempesona. Pihak Pengelola yakni PT. Perhutani (Persero) Unit III Jabar dan Banten membuat strategi dalam mengembangkan Kawasan Objek Wisata Danau Kawah Putih seperti meliputi Renovasi, Sertifikasi, menggelar acara event bertaraf internasional serta melakukan promosi Secara Off Line Dan On Line, termasuk juga meningkatkan mutu objek dengan mengadakan fasilitas pendukung dan menciptakan suasana aman, tenang dan menyenangkan bagi pegunjung yang datang. 


\section{DAFTAR PUSTAKA}

Bahar. 2009. Pariwisata Dalam Ekonomi. Kanisius. Yogyakarta

Brosur. 2011. Dinas Kebudayaan Dan Pariwisata, Bandung

Direktorat Jendral, 1997, Pariwisata Indonesia, Direktorat Jendral Pariwisata, Jakarta

Gamal Suwantoro, 1997, Dasar-Dasar Pariwisata, Andi Yogyakarta

Happy Marpurung, 2002, Gejala Pariwisata, Alfabetha Bandung

Himawan Kertajaya 2009, Manajemen Perjalanan Wisata, Adicitra Karya Nusa, Yogyakarta

Http://www.google.co.id/search?hl=id\&q=20 12/10/04kawasan+wisata+danau+kaw $\mathrm{ah}+$ putih $=10 \&$ sa $=\mathrm{N}$

Kaelany. 2007, Pengembangan Daya Tarik Wisata. Pustaka Sinar Harapan. Jakarta.

Kotler. Philip. 2000 Manajemen Pemasaran. Penerjemah Adi Zakaria Afif. 2002. Jakarta. Lembaga Penerbit FE UI.

Kotler. Philip dan Amstrong. 2001, Pemandu Wisata ( Tour Guiding ), Graha Ilmu, Jakarta

MA. Desky. 2001, Pengantar Bisnis Biro Perjalanan Wisata, Adicitra Karya Nusa, Yogyakarta

M. Kesrul.2003. Penyelenggaraan Operasi Perjalanan Wisata. PT. Grasindo

Moleong, Lexy.J, 2005, Metode Penelitian Kualitatif (Edisi Revisi), Rosdakarya, Bandung.
Nyoman S. Pendit. 1996. Ilmu usaha Dan Perjalanan Wisata. Pradnya Paramitha. Jakarta.

2006, Ilmu Pariwisata, PT. Pradnya Paramita, Jakarta

Oka A. Yoeti, 2007, Pemasaran Pariwisata Terpadu, Angkasa Bandung

RS. Damardjati. 2001, Istilah-Istilah Dunia Pariwisata, Pradnya Paramita, Jakarta

Salah Wahab, 1992, Pemasaran pariwisata, PT. Pradnya Paramita, Jakarta

Sri Wulandari. 2001. Pariwisata dan Pembangunan Ekonomi. Upada Sastra. Denpasar.

Stanton. 1996. Pengembangan Daya Tarik Wisata. Pustaka Sinar Harapan. Jakarta.

Sumadi Suryabrata. 1992. Metodologi Penelitian, Rajawali Pers, Jakarta.

Team Penyusun Materi. Metodologi Penelitian, Program Diploma III, IV, Sekolah Tinggi Pariwisata, Bandung.

Undang-undang Kepariwisataan Republik Indonesia. Ilmu Pariwisata. 2009. Jakarta

Peraturan Daerah. 2010. Propinsi Jawa Barat No. 4

www.perhutani.com 